\title{
Sustainable Coastal Zone Management: Need for a Holistic Approach for Bangladesh
}

\author{
Md Ataur Rahman Khan ${ }^{1}$ \\ ${ }^{1}$ Joint Secretary, Public Investment Management Reform Wing, Programming Division, Bangladesh Planning \\ Commission, Government of the People's Republic of Bangladesh, Sher-e-Bangla Nagar, Dhaka 1207, \\ Bangladesh \\ Correspondence: Md Ataur Rahman Khan, Joint Secretary, Public Investment Management Reform Wing, \\ Programming Division, Bangladesh Planning Commission, Government of the People's Republic of Bangladesh, \\ Sher-e-Bangla Nagar, Dhaka 1207, Bangladesh. E-mail: khanataur71@yahoo.com
}

$\begin{aligned} & \text { Received: September 26, } 2020 \\ & \text { Accepted: October 29, } 2020 \quad \text { Online Published: November 5, } 2020 \\ & \text { doi:10.5539/jms.v10n2p112 }\end{aligned}$ URL: https://doi.org/10.5539/jms.v10n2p112

\begin{abstract}
Coastal Zone is the most vulnerable area which is often attacked by cyclones, storm surges, floods, erosion and affected by climate change impacts like prolonged drought, salinity intrusion \& greater temperature extremes. These realities are true both for the developed nations and a developing country like Bangladesh. This review study aims to explore the coastal management approaches in the UK \& EU and the prevailing coastal management scenarios of Bangladesh. Based on the existing coastal management situations of Bangladesh, this study suggests that Bangladesh needs a holistic coastal management mechanism that should be supported by legislation, run by administrative and institutional frameworks, staffed by multidisciplinary experienced professionals under a Coastal Zone Management Authority (CZMA) for sustainable coastal zone management.
\end{abstract}

Keywords: Bangladesh, coastal zone, CZMA, holistic approach, sustainable coastal zone management

\section{Introduction}

The coast is a dynamic landform where continuous interactions among coastal land, sea and atmosphere take place (Kay \& Alder, 1999; Viles \& Spencer, 1995). The area of intermingling is difficult to measure as it changes frequently, so to say, in minutes and hours (Pethick, 1984). This dynamic coast generates complex coastal processes (Kay \& Alder, 1999, p. 2) which are driven by some external forces. These external forces, often termed as coastal energy, includes coastal wind and climate, river outpouring, waves, currents, tides and some oceanographic phenomena (Masselink \& Hughes, 2003). Coastal areas are characterized by unique opportunities, assorted threats and vulnerabilities (Kay \& Alder, 1999). The importance of the coast is not limited to the source of food and security but it's social, economic and conservation values have drawn the attention of coastal users, policy planners and national \& international communities to sustain its unique features for the sake of humans and biological diversity (Carter, 1988; Davis, 1992). Coastal management has become a core issue for the coastal managers, policy planners, practitioners and researchers (French, 2004). Study shows that conflicts between vested groups, more importantly, between developers and conservationists and among landowners, local authorities \& NGOs are common phenomena in coastal areas (Carter, 1988). In addition, coastal issues like prediction of sea level rise, easing storm hazard, control of seashore erosion, estuary reclamation etc. and coastal risks, such as, impacts of climate change, coastal flooding, coastal erosion, accretion etc. are vital in the domain of coastal management (Carter, 1988; Davis, 1992).

It is evident that although significant developments have been made in the methods and procedures of coastal management, still we see inappropriate coastal development and indiscriminate coastal degradation all over the world (Belfiore, 2003) and Bangladesh is not an exception. This understanding on the nature of coast and the above-mentioned interlinked issues are critical to coastal management (French, 2004). This review study analyses diverse coastal activities \& coastal risks, efficacy \& suitability of existing coastal management approaches and the necessity of a multidisciplinary holistic coastal management approach for sustainable coastal development of Bangladesh. 


\section{Materials \& Methods}

This study was based on secondary information and data which were collected by literature \& documents review. Literature and documents on coastal demographic statistics, government policy papers on coastal management approaches, coastal risk and vulnerabilities were studied carefully. To analyse the similarities \& gaps in the coastal management of Bangladesh, literature on the coastal management of UK \& EU have been studied. The figures used were collected from the published article that have been cited properly.

\section{Coastal Zone of Bangladesh}

Bangladesh, a developing country, is known as a land of rivers and canals. The country is densely populated: around 166.50 million people live within an area of 147,570 square kilometers (BBS, 2019). Bangladesh is one of the largest deltas in the world, at the confluence of three major river systems: the Ganges, the Brahmaputra and the Meghna, and more than 230 rivers and their tributaries and distributaries have formed a riverine network all over the country (Huq \& Ayers, 2008). The country is characterized by flood plains gently sloping from the north to the south, meeting the Bay of Bengal at the southern end (Coastal Zone Policy, 2005). Bangladesh possesses a significant 710 kilometers long coast line along the Bay of Bengal and around one third of the land mass of the country belongs to coastal zone (Coastal Zone Policy, 2005). This coastal area is stretched over in 19 coastal districts (Note 1) of Bangladesh. The districts are Jessore, Narail, Gopalgonj, Satkhira, Khulna, Bagerhat, Pirozpur, Jhalakathi, Barguna, Barishal, Patuakhali, Bhola, Shariatpur, Chandpur, Lakshmipur, Noakhali, Feni, Chattagram and Cox's Bazar (Coastal Zone Policy, 2005). Water area covers 370.40 kilometers from the coastline, estuaries and the internal river water (Coastal Zone Policy, 2005). Around 36.8 million people, representing $22.57 \%$ of the total population of the country, live in the coastal zone (Shafi, Sandra, \& Albrecht, 2016). The Coastal Zone of Bangladesh is composed of various ecological and economic systems like mangrove forest, tidal flat, estuaries, about 70 islands, beaches, rural settlements, urban and industrial area, port and harbor (Iftekhar, 2006).

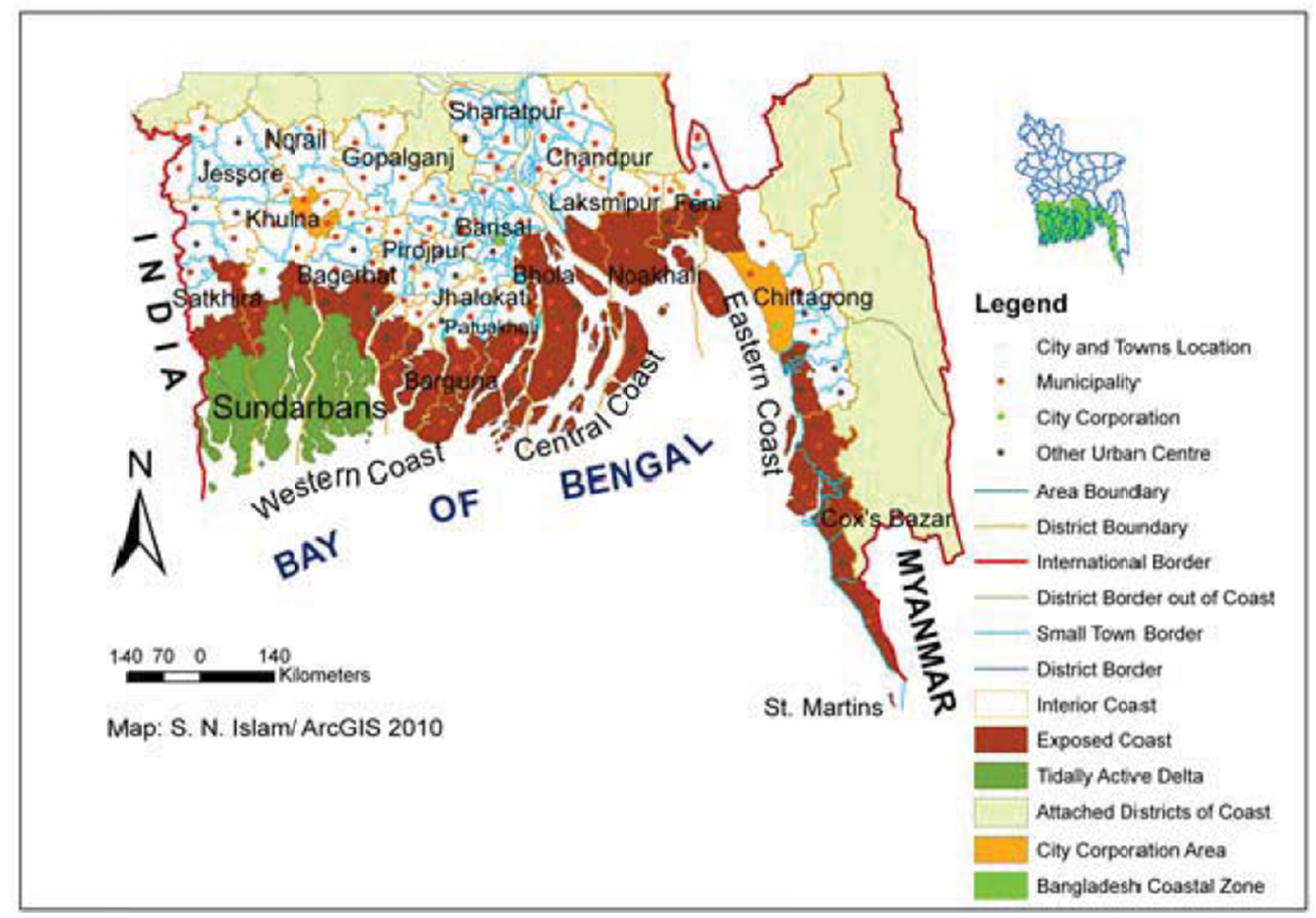

Figure 1. Coastal morphology and ecosystems in Bangladesh

Source: Adopted from Shafi, Sandra, and Albrecht (2016). 
The coastal fauna of Bangladesh are a total 453 species of birds, 42 species of mammals, 35 reptiles and 8 amphibian species. A total of 301 species of mollusks and over 50 species of commercially important crustaceans and 76 species fish from estuarine have been recorded so far in the coastal zone (BNCS, 2016). There are 50 species of brown algae, 82 species of red algae and 26 species of green algae, 5 species of sea grass have so far been reported from Bangladesh coast. In addition, 3 species of lobsters, 7 species of turtles and tortoises, 168 species of seaweeds, 3 species of sponges, 16 species of crabs, 10 species of frogs, 3 species of crocodiles, 24 species of snakes, 3 species of otters, 9 species of dolphins and 3 species of whale, abundance of pelagic fishes like tuna and skipjack, 4 species of mackerel, 14 species of sharks found in Bangladesh territorial water (BNCS, 2016). The coastal marine fisheries sector provides livelihoods opportunities to millions of rural poor and contributes significantly to national food and nutrition security.

\section{Coastal Activities}

Coastal area provides various ecological goods and services in many forms. The economic, socioeconomic and biological activities along coast underpin both its importance for sustaining the ecosystem and fulfilling human needs (Brown, Tompkins, \& Adger, 2002). At the same time these activities in the coastal area create substantial hazards that must be managed by proper techniques and interventions (Kay \& Alder, 1999).

\subsection{Economic/Socioeconomic Activities}

Ports, harbors and their backward linkage industries are situated in the coastal areas. These areas are the foci of the economic activities of the world as most of the world's processed goods and commodities are transported by marine transport through the ports (Davis, 1992). Though these activities are the driving forces for the economy of any country, their impacts on water quality and natural habitats are crucial issues for coastal management (Davis, 1992). Agriculture, fisheries, forestry, aquaculture are important economic activities in coastal areas. All these economic activities have impacts on coastal environments and the coastal managers have been addressing these issues in the UK (Davis, 1992) but in Bangladesh, initiatives to address the impacts are very few (Shafi, Sandra, \& Albrecht, 2016). Mining for mineral sands has economic importance and at the same time it imparts serious impacts on coastlines. Its impacts range from altering flora and fauna populations, vegetation loss, degrading ecosystem to even changing the coastal landscapes (Davis, 1992; Kay \& Alder, 1999). Energy (oil/natural gas) exploration and production is a vital off-shore oceanic activity. The blow-outs and oil spills generated from the exploration processes impinge on the coastal zone and these trials require the installation and operation of contingency plan (Davis, 1992). But is there any clear direction or indication on the agencies responsible to install and execute these plans? The author found no literature on this issue in the context of Bangladesh. The recreational use of coastal zone, for example, intense recreational fishing reduces the growth of fish population, cause destruction of coastal wetlands and marine organism breeding grounds that might have socioeconomic impacts and add a new dimension to be addressed under coastal management (Davis, 1992).

\subsection{Biological Activities}

The sewage of major cities, coastal towns, industrial and agricultural wastes are discharged into the rivers and seas that ultimately fall into the oceans (Davis, 1992). Water bodies digest those sewage and waste materials. As a result, the biological oxygen demand (BOD) (Note 2) of sea water become reduced that causes the loss of valuable sea plants, fisheries, amphibians etc. \& disrupt the marine ecosystem (Australian Government, 1991 cited in Davis, 1992, p. 65). Using oceans and other water bodies as an environmental sink is alarming. It is reported that the biological capacity of coastal water has been exceeded in case of China (Zhijie \& Cote, 1990). Industrial and municipal wastes that are dumped usually in coastal water damage fishery and mariculture (Zhijie \& Cote, 1990). This scenario exists not only in China but it is common in both developing and the developed nations (Davis, 1992). Mangroves are the best suited for shore stabilization and protection and good breeding grounds for juvenile fish and crustaceans (Costanza, Farber, \& Maxwell, 1989). These biological activities demand proper attention of coastal users, managers and planners.

\section{Coastal Risks}

Climate change due to global warming and its impacts are regarded as the scientific realities. The issues associated with climate change are rather complex and interdisciplinary, particularly for the coastal areas (IPCC, 2007). Coastal areas are the heavily populated areas and prop up a number of vital ecosystems on which local communities depend (Kay \& Alder, 1999). Studies show that rising sea levels will originate the loss of livelihoods and coastal land and the expenditure for sea defence will be increased that will pose an extra burden on the economy (Pender, 2008). Coastal flooding, erosion, saline water intrusion and rising water tables are also other detrimental effects of sea level rise (Nicholls, 2011). As most of the land-mass of Bangladesh is situated less than $10 \mathrm{~m}$ above sea level with considerable areas at sea level, frequent and prolonged flooding during 
monsoons is a common phenomenon (Angus, Parris, \& Hassani, 2009).

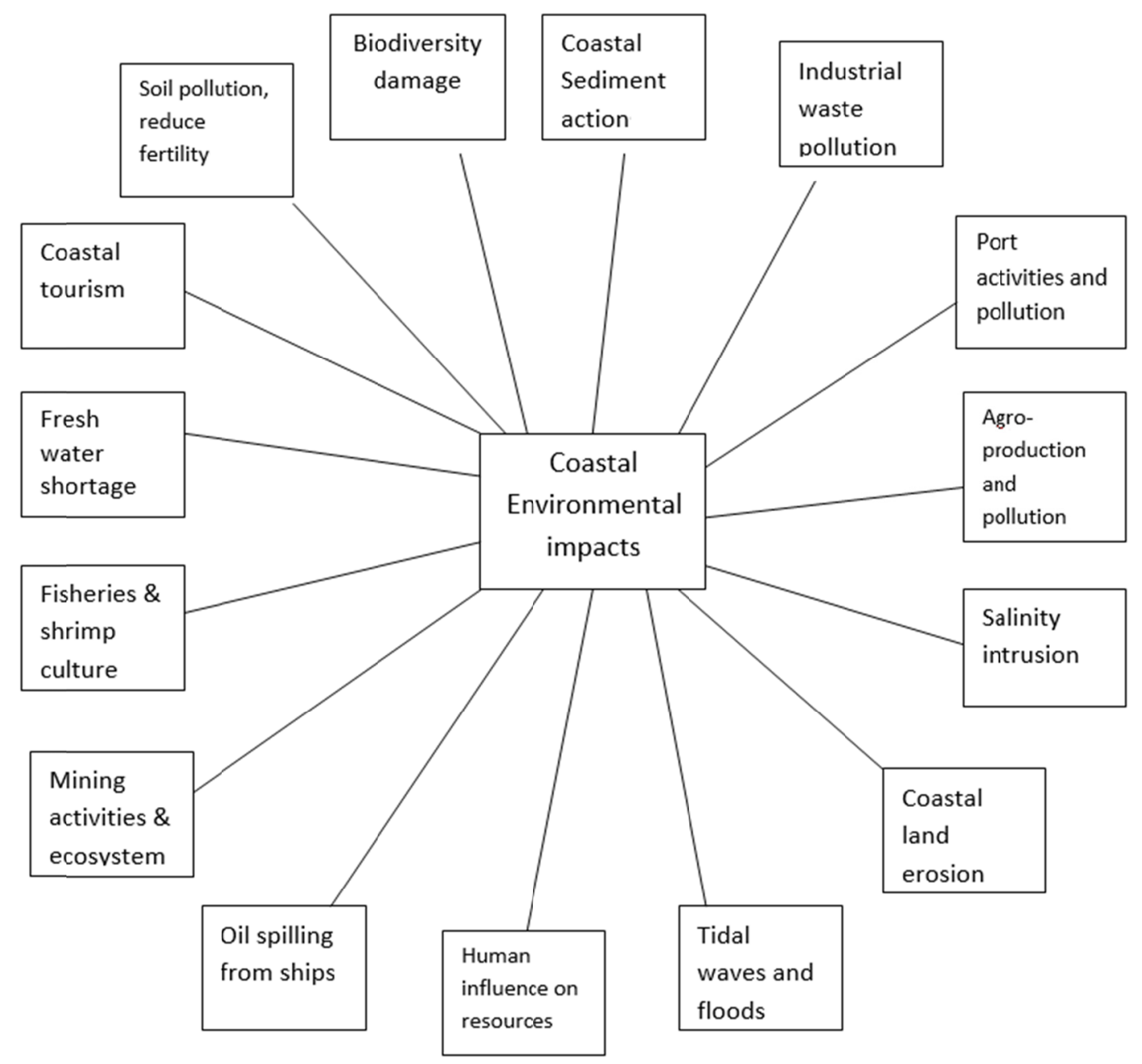

Figure 2. Coastal environmental impacts and linkage to influential elements

Source: Adopted from Shafi, Sandra, and Albrecht (2016)

Nationally important infrastructures like oil refineries, ports and industrial establishments are mostly situated around the coastlines and the consequences of sea level rise are serious threats for these structures (Pender, 2008). Several foremost cities of the world namely Tokyo, Mumbai, Calcutta, New York and London are at menace of flooding due to sea level rise (Stern, 2006). It is also evident that ocean circulation patterns and ocean temperature would be changed due to climate change and these changes affect the biological productivity, nutrients availabilityof the ocean and eventually might impede the smooth functioning of oceanic ecosystem (Pender, 2008). All these issues have distinctive features that should be addressed under sustainable coastal zone management.

\section{Coastal Management: Overall Perspectives}

Defining coastal zone is the first and leading challenge for coastal management (Australian Government, 1991 cited in Davis, 1992). The definition of coastal zone considering the biophysical aspects seems to be effective and extensive (Davis, 1992). Gartside (1988 cited in Davis, 1992, p. 64) defines coastal zone as the "land/sea interface extending from the upper limits of the catchment areas of coastal rivers to the seawards limit of terrestrial influences." This designation of coastal zone implies that coastal resources are interconnected and the management strategies should be integrated rather than piecemeal style (Davis, 1992).

At the very outset of describing various aspects, approaches and effectiveness of coastal management, it is necessary to recap here the essence of sustainable development that has been regarded as a core issue in all resource management since late 1980s. Sustainable development meets the needs of present generation and also 
create the opportunities to meet the demands of future generations both in terms of quality and quantity of resources (WCED, 1987). In this case, as coastal management should be dealt with the economic, biological, social system of the coastal areas, cautious trade-off among these systems might ensure sustainable coastal development (Barbier, 1987 cited in Davis, 1992, p. 71). In addition, it is imperative to concentrate on to prevent misuse or to compensate natural coastal resource base upon which future coastal development depends.

Coastal management in the UK is criticized as imprudent and issue-by-issue basis (Carter, 1989) and taking decision on many coastal issues like power station, erosion etc. are hampered due to lack of firm organizational composition (Bell, 1989 cited in Carter, 1989, p. 48). The operational setup in the coastal zone of England and Wales is regarded as multifarious with the participation of many institutions (Goodhead \& Aygen, 2007). This multi sector involvement is sometimes regarded as the threat of over management (French, 2004). Besides, many organizations share responsibility to solve coastal problems and to use coastal resources but no one own single accountability (Hildebrand \& Norrena, 1992). It seems that everybody's asset is nobody's asset.

To manage the dynamic coast collectively and to overcome the limitations of existing sectoral management of coastal zone, a trans-sectoral model called integrated coastal zone management (ICZM) was developed by EU to solve coastal issues and promote sustainable coastal development (McKenna \& Cooper, 2006). ICZM may be defined as a vibrant process that defend coastal ecosystems and expand coastal assets by implementing a coordinated plan prepared by consulting with local authority and local community (Brown, Tompkins, \& Adger, 2002). In this approach the concept of both science and management is applied together to get better outcome, with a view to preserve the interest of both private and public (Crance \& Draper, 1996).

ICZM is criticized as an ineffective and flawed tool for effective coastal zone management highlighting that the 'bottom up contributory management' of coastal zone can't succeed as it is characterized by lack of legislative power, government policy and direction, default weakness of enforcement, uncertain financial support and project-based focus (McKenna \& Cooper, 2006). It is also opined that the ICZM approach is based on short term model where continuation of a development project is rarely seen and it is near impossible to reach consensus by multi sector participation making the process as a controversial one (McKenna \& Cooper, 2006). It is evident that the short-range personnel under ICZM project suffer from job insecurity and always try to relinquish the job for a better or permanent job. This is also a fundamental issue to be addressed in the mechanism of integrated coastal management (McKenna \& Cooper, 2006). ICZM compromises with past loopholes and the involved parties concentrate on easy-going issues and pass up those that are difficult to achieve by consensus (McKenna \& Cooper, 2006). In most of the cases, the consensus seeking process is time consuming and even guide to management indolence that eventually goes beyond public interest (McKenna \& Cooper, 2006).

It is evident that there are concerns at EU level regarding the short of appreciation of heritage in ICZM (Goodhead \& Aygen, 2007). The same study shows that ICZM is limited with coastal land and marine environment and rarely acknowledge heritage issues that limits its application to achieve sustainable development (Goodhead \& Aygen, 2007). It is generally seen that decisions on resource allocation and management is mainly run by non-scientific organizations where scientific knowledge is under represented (Holmes, Davis, \& Dutton, 1992 cited in Davis, 1992). ICZM has been experimented in various situations basically at sectoral and sub-national level through voluntary mechanism (Atkins, 2004). An integrated overview is necessary to make its application fruitful for sustainable coastal management (Atkins, 2004). Very recently planned approaches like integrated strategies for estuaries and harbors and shoreline management plans (SMP) are coming into force under ICZM mechanism and these ideas have been achieved impetus in the UK coastal management (Taussik, 2007). Coastal resource management is rather complex as it deals with interrelated biological, economic and social aspects of the dynamic zone. So in the case of coastal resource management, the integration of science (in the form of scientific validity and sequence) and managerial expertise is a must for proper taking care of coastal issues (Davis, 1992).

Relative sea level rise (RSLR) due to global warming is a scientific reality and it poses a new threat in the coastal management phenomena. Two important rejoinders to RSLR should be acknowledged and addressed by the coastal authority (Nicholls, 2011). Mitigation is a global level movement that could be addressed by friendly climate policy whereas adaptation is local or national level initiative related to coastal management policy (Nicholls, 2011). In the framework of coastal area, mitigation is aimed at to avoid activities that exacerbate sea level rise and adaptation is mainly seen as a public rather than individual task where management requires to select response strategy like planned retreat, or accommodate or protect the impacts (Klein et al., 2000 in Nicholls, 2011, pp. 151-152). In this respect three groups of professionals namely engineers, planners and environmentalists should work together to formulate strategies whether hard solutions like sea walls, groynes or soft technique like marsh creation or beach nourishment or the blending of both the techniques, would be 
adopted for solving particular coastal problem (Carter, 1989). Despite serious criticism on the effectiveness of ICZM, its aims and objectives might be realized if it gets institutional shape by legislation, staffed by experienced personnel, supported by top management and plans with assurance of recurrent funding (McKenna \& Cooper, 2006)

\section{Coastal Management: Bangladesh Perspectives}

The vulnerability of Bangladesh to climate change impacts, specially the coastal area, is characterized by its flat and low-lying land, poor coastal community, and reliance of many livelihoods on climate sensitive sectors such as agriculture \& fisheries and insufficient institutional development (Huq \& Ayers, 2008). Due to climate change, Bangladesh had been facing various environmental, socio-economic and demographic stresses like increased flooding, vulnerability to cyclone and storm surges, increased drought, salinity intrusion, epidemics associated with greater temperature extremes (Huq \& Ayers, 2008). The population of the coastal zone are the worst victims of these calamities.

Coastal erosion is a common phenomenon in Bangladesh. The Meghna estuary (Note 3), the east coast of Hatiya (Note 4), South western coast of Sandwip (Note 5) are the major coastal areas where constant erosion occurs (Ahmed, Darke, \& Woulds, 2018). Study shows that the vulnerability of coastal zone of Bangladesh will be increased in future in comparison to present scenario (Uddin, Islam, Bala, Islam, Adhikary, \& Saha, 2018). Since the independence of the country in 1971, several initiatives, policy documents have been prepared for the management of coastal zone of the country. Though all the initiatives are based on the essence of ICZM, we see limited prudence in effective management of coastal zone (Ahmad, 2019). The Coastal Environment Management Plan for Bangladesh, adopted in 1987 (UNESCAP, 1987) and Bangladesh National Conservation Strategy, first adopted in 1993 and subsequently updated in 2016, emphasized on the proper utilization of coastal land \& resources through a proper coastal land use planning. It also laid importance on proper planning and formulation of management standards \& guidelines for coastal \& marine development (BNCS, 2016).

The ICZM initiative, first introduced in Bangladesh in 1997, was basically on the capacity building on coastal zone management. Getting experiences from ICZM approach and consulting with relevant stakeholders, two policy documents: Bangladesh Coastal Zone Policy 2005 and Bangladesh Coastal Development Strategy 2006, have been formulated to ensure sustainable livelihoods of the coastal population and to integrate coastal issues such as vulnerable coastal community, optimum use of coastal resources, protection and conservation of coastal environment, coastal economy, coastal flora, fauna etc. into national planning and development process for sustainable coastal development (Coastal Zone policy, 2005).

In Bangladesh, coastal disasters are addressed by the Directorate of Disaster Management (DDM) under Ministry of Disaster Management \& Relief (MoDMR, 2020); coastal afforestation protection \& preservation, creation of coastal green belt are maintained by the Directorate of Forest (DoF) under Ministry of Environment, Forest \& Climate Change (MoEFCC, 2020); mitigating the impacts of climate change, protecting coastal flora \& fauna and controlling environmental pollution are administered by Directorate of Environment (DoE) under MoEFCC; sustainably managing the coastal fisheries \& marine resources are maintained by Directorate of Fisheries (DoF) under Ministry of Fisheries \& Livestock (MoFL, 2020); coastal erosions are controlled and prevented by Bangladesh Water Development Board (BWDB) under Ministry of Water Resources (MoWR, 2020); sustainable $\&$ integrated water management planning including coastal, marine $\&$ estuarine are done by Water Resources Planning Organization (WARPO, 2020) under MoWR, extension services to produce different crops suitable for coastal zone are provided by Directorate of Agricultural Extension (DAE) under Ministry of Agriculture (MoA, 2020). Local Administrative Units, mainly District Administration, Upazilla Administration (Note 6) \& Union Parishad (Note 7), situated in the coastal area, perform the administrative tasks that need immediate actions to be performed. It is seen that many authorities (Directorates, Ministries) are involved in managing various activities of coastal zone of Bangladesh.

The Coastal Zone Policy of Bangladesh (CZP 2005) states that all concerned Ministries, Agencies, Local Government Institutions (LGIs), Non-Government Organizations (NGOs), Private Sectors, Civil Society Organizations (CSOs), will put their efforts for the development of coastal zone. To co-ordinate these activities, a lead ministry, Ministry of Water resources (MoWR) \& a lead agency, Water Resources Planning Organization (WARPO, 2020) has been designated. But reviewing the existing coastal management approaches, it is seen that there exists weakness in clear mechanism of coordination \& harmonization among the concerned authorities, prioritization of investment and investment patterns, human resource management, participatory mechanism for coastal development and in the cases of resolving coastal conflicts. As a result, the concerned beneficiaries, coastal community in particular, can't grasp the full benefit of the rich coastal zone of Bangladesh. Besides, 
some vital issues such as protection and conservation strategy of ecosystem \& biodiversity, protection \& development of coastal economy, protection of coastal erosion based on hydrological \& geomorphological studies, monitoring \& evaluation of environmental resilience of natural coastal processes, should be addressed in a holistic way for sustainable coastal development. The author finds little study on these issues in the context of Bangladesh. An authority, formed by law, run by regulation and staffed by multi sector professionals, could take appropriate development and protective actions to ensure sustainable coastal development.

\section{Conclusion}

There is little doubt that day by day coastal population will be increased and intense use of coastal resources together with likely impacts of climate change will make coastal management a difficult task. Various activities at the coastal zone create numerous hazards. The biological degradation of marine ecosystem is not only a threat for aquatic life but it also poses threats for humans. Coastal flooding, storm surges, catastrophes like tsunami are likely events that can hit coastal areas at any time causing loss of assets and death of humans and animals. Coastal wetlands, habitats, beach dunes demand individual treatment for protection and preservation. Coastal problems are linked to one another. Problems in wetland affect the adjacent seashore and vice versa. Government involvement and dedicated political determination are vital to address these issues. In this regard, ICZM is essential but integration of science and management, mechanism for coastal conflicts resolution, people's participation and strategic development planning for coasts should be given more focus in this approach And to achieve the optimum outcomes from coastal areas and to avoid further coastal mismanagement, establishment of a dedicated Coastal Zone Management Authority (CZMA) could be an option for sustainable coastal zone management of Bangladesh. Permanent multidisciplinary professionals recruited under CZMA, mandated to plan, execute, supervise, harmonize and regulate all sectors involved, would be able to cater the best benefits from the dynamic coastal zone of Bangladesh.

\section{Acknowledgement}

Special thanks to the Government of Bangladesh for granting the scholarship \& sanctioning the deputation to pursue the post graduate study in the UK. My sincere gratitude to Mr. Paul Rooney, Senior Lecturer \& Dr. Kevin Crawford, Senior lecturer, Department of Geography \& Environmental Science of Liverpool Hope University, UK, for their guidance to write few review articles during my M.Sc study in the UK.

\section{Disclaimer}

The analysis, opinions, conclusion expressed in the article are those of the author \& do not necessarily represent the views of any ministry/division/agency of Bangladesh Government.

\section{References}

Ahmad, H. (2019). Bangladesh Coastal Zone Management Status and Future Trends. Journal of Coastal Zone Management, 22(1).

Ahmed, A., Darke, F., \& Woulds, C. (2018). Where is the Coast? Monitoring coastal land dynamics in Bangladesh: An integrated management approach using GIS \& Remote Sensing Techniques. Ocean \& Coastal Management, 151(1), 10-24. https://doi.org/10.1016/j.ocecoaman.2017.10.030

Angus, S. D., Parris, B., \& Hassani, M. B. (2009). Climate Change Impacts and adaptation in Bangladesh: An agent-based approach. 18th World IMACS/MODSIM Congress, Cairns, Australia 13-17 July 2009. Retrieved from http://mssanz.org.au/modsim09

Atkins. (2004). ICZM in the UK: A Stocktake. London: HMSO.

Australian Government. (1991). The Injured Coastline: Protection of the Coastal Environment. Report of the House of Representatives Standing Committee on Environment, Recreation and Arts. Journal of Environmental Education and Information, 11, 63-72.

Bangladesh Bureau of Statistics (BBS). (2019). Statistics \& Informatics Division. Ministry of Planning, Government of Bangladesh. Retrieved from http://www.bbs.gov.bd/

Bangladesh Natural Conservation Strategy (BNCS). (2016). Ministry of Environment Forest \& Climate Change (MOEFCC). Government of Bangladesh. Retrieved from http://www.moef.gov.bd

Barbier, E. B. (1987). The Concept of Sustainable Economic Development. Environmental Conservation, 14(2), 101-110. https://doi.org/10.1017/S0376892900011449

Belfiore, S. (2003). The growth of integrated coastal management and the role of indicators in integrated coastal management: Introduction to the special issue. Ocean and Coastal Management, 46, 225-234. 
https://doi.org/10.1016/S0964-5691(03)00005-X

Bell, P. (1989). A County Council's Approach. In R. W. G. Carter (Ed.), Coastal Zone Management: Comparisons and Conflicts. Sefton Metropolitan Borough Council, Southport.

Brown, K., Tompkins, E. L., \& Adger, W. N. (2002). Making Waves: Integrating Coastal Conservation and Development. Earthscan.

Carter, R. W. G. (1988). Coastal Environments: An introduction to the physical, ecological and cultural systems of coastlines. Academic Press.

Coastal Zone Policy of Bangladesh. (2005). Ministry of Water Resources. Government of the People's Republic of Bangladesh. Retrieved from http://www.mowr.gov.bd

Costanza, R., Farber, S. C., \& Maxwell, J. (1989). Valuation and Management of Wetland Ecosystems. Ecological Economics, 1, 335-361. https://doi.org/10.1016/0921-8009(89)90014-1

Crance, C., \& Draper, D. (1996). Socially Co-operative Choices: An Approach to Achieving Resource Sustainability in the Coastal Zone. Environmental Management, 20, 175-184. https://doi.org/10.1007/BF01204002

Davis, D. (1992). Issues in Coastal Zone Management. Journal of Environmental Education and Information, 11, 63-72.

French, P. W. (2004). The Changing Nature of, and Approaches to, UK Coastal Management at the start of the twenty-first century. The Geographical Journal, 170, 116-125. https://doi.org/10.1111/j.0016-7398.2004.00113.x

Gartside, D. F. (1988). Management of the Resources of the Coastal Zone: Introductory Comment. Proceedings of the 1988 Workshop on Coastal Zone Management, Lismore.

Goodhead, T., \& Aygen, Z. (2007). Heritage Management Plans and Integrated Coastal Management. Marine Policy, 31, 607-610. https://doi.org/10.1016/j.marpol.2007.03.005

Hildebrand, L. P., \& Norrena, E. J. (1992). Approaches and Progress toward Effective Integrated Coastal Zone Management. Marine Pollution Bulletin, 25, 94-97. https://doi.org/10.1016/0025-326X(92)90194-B

Holmes, N., Davis, D., \& Dutton, I. (1992). Information needs in Coastal Management: The Role of Science. Journal of Environmental Education and Information, 11, 63-72.

Huq, S., \& Ayers, J. (2008). Climate Change Impacts and Responses in Bangladesh. International Institute for Environment and Development (IIED), London, United Kingdom.

Iftekhar M. S. (2006). Conservation and Management of Bangladesh coastal ecosystem: Overview of an integrated approach. Natural Resources Forum, 30(3), 230-237. https://doi.org/10.1111/j.1477-8947.2006.00111.x

Intergovernmental Panel on Climate Change (IPCC). (2007). Climate Change 2007: Impacts, Adaptation and Vulnerability. Contribution of Working Group II to the Fourth Assessment Report of the IPCC, UK: Cambridge University Press.

Kay, R., \& Alder, J. (1999). Coastal Planning and Management. Spon Press. https://doi.org/10.4324/9780203010174

Klein, R. J. T., Aston, J., Buckley, E. N., Capobianco, M., Mizutani, N., Nicholls, R. J., ... Ragoonaden, S. (2000). Coastal Adaption.

Masselink, G., \& Hughes, M. G. (2003). Introduction to Coastal process and Geomorphology. Arnold.

McKenna, J., \& Cooper, A. (2006). Sacred cows in coastal management: the need for a 'cheap and transitory' model. Area, 38, 421-431. https://doi.org/10.1111/j.1475-4762.2006.00708.x

Ministry of Agriculture (MoA). (2020). Government of Bangladesh. Retrieved from http://www.moa.gov.bd/

Ministry of Disaster Management \& Relief (MoDMR). (2020). Government of Bangladesh. Retrieved from http://www.modmr.gov.bd

Ministry of Environment Forest \& Climate Change (MoEFCC). (2020). Government of Bangladesh. Retrieved from http://www.moef.gov.bd

Ministry of Fisheries \& Livestock (MoFL). (2020). Government of Bangladesh. Retrieved from http://www.mofl.gov.bd 
Ministry of Water Resources (MoWR). (2020). Government of Bangladesh. Retrieved from http://www.mowr.gov.bd/

Nicholls, R. J. (2015). Planning for the Impacts of Sea Level Rise. Oceanography, 24(2), 144-157. https://doi.org/10.5670/oceanog.2011.34

Pender, J. S. (2008). What Is Climate Change? And How It Will Effect Bangladesh? Briefing Paper (Final Draft). Dhaka, Bangladesh: Church of Bangladesh Social Development Program.

Pethick, J. (1984). An Introduction to Coastal Geomorphology. Edward Arnold.

Shafi, N. I., Sandra, R., \& Albrecht, G., (2016). Coastal Environmental Degradation and Ecosystem Management in the Ganges Deltaic Region in Bangladesh. International Journal of Ecological Economics \& Statistics, $37(4)$.

Stern, N. (2006). Report of the Stern Review: The Economics of Climate Change. London: HM Treasury. https://doi.org/10.1017/CBO9780511817434

Taussik, J. (2007). The opportunities of spatial planning for integrated coastal management. Marine Policy, 31, 611-618. https://doi.org/10.1016/j.marpol.2007.03.006

Uddin, M. N., Islam, A. K. M. S., Bala, S. K., Islam, G. M. T., Adhikary, S., \& Saha, D. (2018). Mapping of Climate vulnerability of the coastal region of Bangladesh using principal component analysis. Applied Geography, 102, 47-57. https://doi.org/10.1016/j.apgeog.2018.12.011

United Nations Economic \& Social Commission for Asia \& the Pacific (UNESCAP). (1987). Bangkok. Thailand.

Viles, H., \& Spencer, T. (1995). Coastal Problems: Geomorphology, Ecology and Society at Coast. Arnold.

Water Resources Planning Organization (WARPO). (2020). Government of Bangladesh. Retrieved from http://www.warpo.gov.bd/

World Commission on Environment and Development (WCED). (1987). Our common future. WCED, Oxford University Press.

Zhijie, F., \& Cote, R. P. (1990). Coastal Zone of People's Republic of China: Management, Approaches and Institutions. Marine Policy, 4(4), 305-314. https://doi.org/10.1016/0308-597X(90)90052-S

\section{Notes}

Note 1. District is an administrative unit in Bangladesh. There are 64 districts in Bangladesh; each district has a definite area and official jurisdiction.

Note 2. BOD-Biological oxygen demand is the amount of oxygen consumed by bacteria \& other microorganisms while they decompose organic matter under aerobic condition.

Note 3. Meghna estuary is a coastal plain estuary on the coast of Bangladesh.

Note 4. Hatiya is an island along the southern coast under Noakhali district of Bangladesh.

Note 5. Sandwip is an island along the south eastern coast under Chattagram district of Bangladesh.

Note 6. Upazilla is a sub-administrative unit under District administration.

Note 7. Union Parishad is the lowest level local administration unit under Upazilla.

\section{Copyrights}

Copyright for this article is retained by the author, with first publication rights granted to the journal.

This is an open-access article distributed under the terms and conditions of the Creative Commons Attribution license (http://creativecommons.org/licenses/by/4.0/). 